\title{
Selecting the ideal adjuvant to improve neuraxial and regional analgesia: A narrative review
}

\author{
Dmytriiev Dmytro, Nazarchuk Oleksandr $\varangle$, Dmytriiev Kostiantyn $\bowtie$, \\ Lysak Evgenii $\bowtie$, Zaletska Olesya $\bowtie$
}

Authors' affiliation:

National Pirogov Memorial Medical University, Pyrohova St, 56, Vinnytsia, Vinnytsia Oblast, Ukraine, 21018

Correspondence: Dmytriiev Dmytro; E-mail: dmytrodmytriiev@gmail.com, Tel.: +380674309449

\section{Abstract}

Introduction: The aim of this review was to systematize known facts about the effects of adjuvants to local anesthetics for neuraxial and regional analgesia in order to determine the adjuvant with the best effect among all others. More precisely to consider the time to onset, the strength of the effect, duration of the motor and sensory block and some additional effects such as 'marker of intravascular injection', safety and toxicity profile. We aimed to find an ideal adjuvant which has all these properties to a good degree.

Methodology: For this narrative review we searched the information in Medline, PubMed, Scopus, and Embase databases. 105 articles were identified regarding the topic, published since 1989 to 2020. Data from 105 articles about adjuvants to local anesthetics was analyzed and synthesized in this review.

Results: Regional methods of analgesia are becoming a crucial part of anesthesiologists' practice and the knowledge about adjuvants is developing alongside with it, so there are more and more studies devoted to it. All of them try to find the "ideal" adjuvant, having sufficient necessary effects, but we think that due to the difference in various classes of adjuvants, some may be better than others. However, use of combination of adjuvants is not desirable at all times.

Conclusion: A variety of adjuvants to local anesthetics are available now, yet the data about most of them remains inconclusive, so more studies are required to found out the best adjuvants with the most desirable profile and the least adverse effects

Key words: Local anesthetic; Adjuvants; Pain management; Regional anesthesia.

Citation: Dmytro D, Oleksandr N, Kostiantyn D, Evgenii L, Olesya Z. Selecting the ideal adjuvant to improve neuraxial and regional analgesia: A narrative review. Anaesth. pain intensive care 2020;24(6):682-693; DOI: 10.35975/apic.v24i6.1209

Received: 24 March 2020, Reviewed: 23 April, 25 June 2020, Revised: 18 October 2020, Accepted: 27 October 2020

\section{Introduction}

Modern toolkit of anesthesiologist includes a wide spectrum of methods of regional anesthesia, such as neuraxial and peripheral nerve blocks, which can also be used for various pain management procedures. ${ }^{1}$ Every method has its pros and cons, but regional methods are considered the safest one's now a days. There is a variety of interventions where regional analgesia can be used to achieve specific goals depending upon the specific circumstances in each case, especially in multiple organ dysfunction syndrome (MODS). ${ }^{2}$ These goals can be achieved by potentiating certain effects of local anesthetics or evading the adverse effects achieved by using adjuvants to local anesthetics. 
A large number of clinical studies aimed to search an ideal adjuvant to local anesthetics. For example in urgent surgery, a time to onset of sensorimotor block, but not the duration of postoperative analgesia, can be the primary effect. The need to start the surgery urgently after an urgent block in the stressful situation and lack of time may lead to inadvertent intravascular injection of local anesthetic or crossing the maximal safe dose.

The aim of this review is to systematize known facts about the effects of adjuvants to local anesthetics in order to determine an adjuvant with the most desirable effects among all others, including the time to onset, strength of the effect, duration of the block and some additional effects such as 'marker of intravascular injection', safety and the toxicity profile of the agent.

\section{Methodology}

For this narrative review we searched for information in Medline, PubMed, SCOPUS and Embase. 105 articles were included into this review, published since 1989 to 2020. Data from these articles about adjuvants to local anesthetics was analyzed and synthesized in this article. Key word for search were: 'adjuvant', 'regional analgesia', 'neuraxial analgesia'. Articles that provided insufficient information or had no data available for extraction, ongoing studies, the articles published in foreign languages with no translation available, and articles not available for the review through library services, were not analyzed and included in this narrative review.

We also did not included case reports.

\section{Discussion}

In the following paragraphs main pharmacological agents used as adjuvants to local anesthetics out of each known groups will be discussed in brief.

\subsection{Vasoactive agents}

\subsubsection{Alpha-2-receptors agonists:}

Two most widely used alpha-agonists now a days are, clonidine and dexmedetomidine. Clonidine is a derivative of imidazole, which was earlier used as an adjuvant to local anesthetics. Clonidine is alpha-2agonist, and has analgesic, hemodynamic and sedative effect during neuraxial and peripheral blocks.
3.1.2. Clonidine: is selective to alpha-2adrenoceptors that are located on the primary afferent paths inside the spinal cord and brain stem. It also acts through the nucleotide-ion channels. It is considered that during peripheral nerve blocks clonidine blocks conduction in $\mathrm{A}$ and $\mathrm{C}$ fibers by increasing the potassium permeability. ${ }^{3,4}$ Clonidine can also produce local vasoconstriction, that can prolong action of local anesthetic by slowing its uptake from the place of action. ${ }^{5}$ A meta-analysis has shown an increase by 2 hours in the duration of action of moderate and long-acting local anesthetics when used with clonidine. ${ }^{5}$ Another systematic review by McCartney et al. has shown longer anesthesia with moderate-acting local anesthetic, when used with clonidine ${ }^{6}$.

Several authors have shown that clonidine is capable of increasing block duration for two hours, and it was also reported, that effect was better in terms of quality of analgesia, when clonidine was used together with long-acting anesthetics. Authors also reported systemic adverse events such as hypotonia and bradycardia at high doses of clonidine..$^{5,7,8}$

3.1.3. Dexmedetomidine is an alpha-2adrenoreceptor agonist, which has hypnotic, analgesic, hypotensive effects and is capable of decreasing heart rate. Intrathecal administration of dexmedetomidine together with bupivacaine demonstrated an increase in motor and sensory block duration. ${ }^{9}$ Dexmedetomidine can prolong peripheral block for $200 \mathrm{~min}$ in the dose $1 \mathrm{mcg} / \mathrm{kg}$. It prolongs duration not only of short-acting, but also long-acting local anesthetics. One of the metaanalysis have shown a presence of reversible bradycardia. ${ }^{10}$ Another meta-analysis reviewed 14 clinical studies with 848 patients, where perineural administration of dexmedetomidine vs clonidine was compared. It was shown, that dexmedetomidine prolonged motor and sensor block. ${ }^{11,12}$ Dexmedetomidine effect exceed such of clonidine in seven times. ${ }^{13,14}$ Another study by Andersen et al. compared perineural administration vs. intravasculare use of dexmedetomidine. Both ways it prolonged action of ropivacaine, but perineural administration was more effective when compared to systemic use. ${ }^{12}$

Dexmedetomidine has such adverse effects as hypotonia and bradycardia. ${ }^{15}$ There is no data about neurotoxicity of dexmedetomidine in humans and animals, but there is still discussion around the neurotoxicity of dexmedetomidine after its 
perineural administration in patients with diabetic neuropathy. More studies should be performed to confirm or negate this hypothesis. ${ }^{16,17}$

\subsubsection{Adrenaline is known as an adjuvant to} local anesthetics for a long time and now a days is probably the most widely used adjuvant to local anesthetics for regional anesthesia. It can prolong the action of local anesthetics by decreasing systemic resorption of local anesthetic. This feature can also decrease systemic toxicity of local anesthetic, that can promote administration of higher doses and increase the block density. ${ }^{18,19}$ Adrenaline also has alpha-2 receptor mediated anti-nociceptive effect.

Negative hemodynamic reactions are rarely observed after adrenaline use as an adjuvant, but tachycardia and hypertension are possible after its intravascular injection which can be used as a marker of intravascular injection. ${ }^{20}$ Addition of adrenaline $5 \mathrm{mcg} / \mathrm{ml}$ to $1 \%$ lidocaine have shown an increase of block duration by 5 times. An increase of sensory and motor block was shown in the block of axillary nerves with lidocaine and brachial plexus with mepivacaine and bupivacaine. But addition of epinephrine does not change time of onset of action of ropivacaine..$^{21,22}$

Despite some benefits of adrenaline as the adjuvant, it can significantly limit blood circulation in kidneys. ${ }^{23}$ This can have negative consequences in patients with diabetes mellitus with polyneuropathy. An increase of neurotoxicity has been shown in animal studies. ${ }^{24,25}$

\subsection{Opioids}

Opioids can be considered as the oldest adjuvants. Direct analgesic effects occurs after the action on antinociceptive structures, such as G-protein associated hyperpolarization of afferent sensor neurons. Opioids have a good credit in neuraxial blocks, but the data are controversial about their perineural administration.

3.2.1. Buprenorphine is a semisynthetic partial agonist of opioid receptors, which can also block voltage-dependent sodium channels. Intermediate metabolite of buprenorphine norbuprenorphine act not only through mu-opioid receptors, but also through kappa and delta opioid receptors. ${ }^{26,27,28}$

Buprenorphine was used as an adjuvant for different regional techniques such as neuraxial, intravenous and peripheral nerve blocks. ${ }^{29}$ Studies $^{30,31}$ have shown that a combination of buprenorphine and levobupivacaine can double the time of analgesia during brachial plexus block.

Several studies have shown, that buprenorphine can significantly increase average duration of analgesia for the nerve blocks of upper and lower limbs. Candido et al. published several studies, where they showed an increase of duration in 1.5 to 3 times for analgesia of subclavicular, axillary and iliac nerves with the addition of buprenorphine. ${ }^{32,33}$ Available data have shown perspectives of buprenorphine used, but more studies are yet required. Buprenorphine is relatively safe drug for use, but several studies have shown an increase of nausea and vomiting after its administration.

3.2.2. Morphine: There is no doubt about good result of intrathecal and epidural administration of morphine, ${ }^{34,35}$ while its use as an adjuvant for the peripheral nerve blocks is doubtful and did not show any effect in most of the cases. ${ }^{36}$ No benefits of perineural administration of morphine were shown when compared to intramuscular use. Taking into account the absence of evidence it is not recommended for perineural blocks.

3.2.3. Fentanyl: In studies, that compared fentanyl with local anesthetics such as lidocaine, mepivacaine, ropivacaine for peripheral nerves blocs, the authors did not show any significant difference. But there was a prolongation of effect to 18 hours in a study, where a combination of bupivacaine, fentanyl and adrenaline was used for paravertebral blocks. ${ }^{37}$ There was also positive result of using a combination of bupivacaine, fentanyl and lidocaine for cervical plexus blocks.

3.2.4. Tramadol is a weak opioid, that also block sodium, potassium, noradrenergic and serotonin receptors..$^{37,38,39}$ Use of tramadol as adjuvant to local anesthetics for peripheral blocks is doubtful. ${ }^{41,42}$ So its use is recommended only for the postoperative epidural infusion. ${ }^{40}$

\subsection{NMDA antagonists}

Ketamine and magnesium can be considered as NMDA antagonists in this context.

3.3.1. Ketamine has local analgesic effect and can decrease nerve conduction due to the block of NMDA receptors. ${ }^{20}$ Ketamine is used for the treatment of acute pain, palliative care and chronic neuropathic pain. Lower doses can be used for 
postoperative analgesia or for the decrease of exogenous opioid hyperalgesia. Combination of ketamine and opioid significantly decrease pain scores, total morphine use and postoperative desaturation in patients after thoracic surgery.

Intravenous infusion of ketamine can be used for treatment of severe neuropathic pain, such as complex regional pain syndrome, postherpetic neuralgia, trauma of the spinal cord and phantom pain. ${ }^{43}$ There is very little data available regarding perineural ketamine use for regional anesthesia. Lee et al. showed that ketamine did not affect sensory and motor block at its perineural use and had high amount of complications. ${ }^{45}$ Adverse events of ketamine include hallucinations, memory defects, panic attacks, nausea, vomiting, sleepiness, sympathetic stimulation and cardiac depression. ${ }^{4}$ So, ketamine is not recommended as an adjuvant to local anesthetics. ${ }^{40}$

3.3.2. Magnesium modulates potassium flow into the cell through NMDA receptors and has potential benefits as an adjuvant. It was shown that addition of magnesium prolongs the duration of peripheral nerve blocks with bupivacaine, procaine and levobupivacaine. ${ }^{46,47}$

There is also an information, that magnesium can increase activity of lidocaine through the increase of threshold of A-beta fibers, as shown in experimental rat models. ${ }^{48}$ An important benefit of magnesium is that none of the studies reported any adverse effects related to this adjuvant. Studies have shown that addition of magnesium can prolong femoral nerve block, interscalene and axillary blocks. ${ }^{49}$

Doses higher than $150 \mathrm{mg}$ can be associated with higher risks of nausea and vomiting. More studies regarding neurotoxicity of magnesium should be performed before its routine use for peripheral blocks. ${ }^{17}$

\subsubsection{Midazolam is a short-acting} benzodiazepine, and acts as a GABA-A receptor agonist in central nervous system (CNS). There is some evidence, that GABA-A receptors are located not only in CNS, but there are not enough data on the mechanism of action of benzodiazepines in peripheral nervous system. Translocator protein (TSPO), which was previously known as benzodiazepine receptor (BDR), is considered a peripheral target of midazolam. ${ }^{50}$ TSPO is located throughout the body, were it functions as a protein, which binds cholesterol at the external mitochondrial membrane for the steroid production. It was also determined that TSPO plays a protective role in microglial cells after the nerve damage. ${ }^{51}$

A double-blind, prospective, randomized trial studied use of midazolam as an add-on during brachial plexus blocks with bupivacaine in 50 patients. Patients were divided into two groups: one group received $30 \mathrm{ml} 0.5 \%$ bupivacaine with $2 \mathrm{ml}$ of $0.9 \% \mathrm{NaCl}$ or $30 \mathrm{ml} 0.5 \%$ bupivacaine with 0.05 $\mathrm{mg} / \mathrm{kg}$ of midazolam. Despite the small sample size, the results were significant for the average pain scores decreased and lower pain scores in 12 hours in the group receiving midazolam. The only adverse effect in midazolam group was a decrease of breathing rate 10-30 min after the injection. This decrease did not require any intervention except of addition of oxygen through the face mask. ${ }^{52}$

A recent article studied efficacy of midazolam as an adjuvant during peribulbar block for cataract surgery. Midazolam in concentrations of $50 \mathrm{mcg} / \mathrm{ml}$ and $100 \mathrm{mcg} / \mathrm{ml}$ was combined with lidocaine and hyaluronidase. An average time of sensory block, but not the motor block, was significantly lower in midazolam groups. Total duration of motor and sensor analgesia was also longer in midazolam groups. ${ }^{53}$

Data considering midazolam safety is limited and there is not sufficient amount of in vivo studies. Some in vitro studies indicate potential toxicity of perineural use of midazolam, but this was not proved in in vivo studies. ${ }^{54}$ More randomized controlled trials are required before any recommendations considering midazolam use as the adjuvant to regional anesthesia.

\subsection{Anti-inflammatory drugs}

\subsubsection{Non-steroidal anti- inflammatory drugs (NSAIDs) act} through the inhibition of COX-1, COX-2 or both enzymes. In one study ketorolac as an adjuvant to lignocaine improved analgesia in operations of the foot. ${ }^{56}$ In comparative study of ketorolac and dexmedetomidine ketorolac did not show benefits in the duration and onset time of the block. ${ }^{56}$ Animal models provide controversial conclusions regarding neurotoxicity of NSAIDs. ${ }^{15,57}$

One study assessed the efficacy of combined use of lidocaine with dexketoprofen or acetaminophen as an adjuvant to regional intravenous analgesia. They found that both combinations decrease the time of onset and duration of sensory and motor block when 
compared to control groups. There was no significant difference between paracetamol and dexketoprofen. There is yet not enough data for routine use of NSAIDs in practice for regional blocks.

3.4.2. Dexamethasone is a synthetic longacting corticosteroid, with a broad spectrum of physiological effects. Except of direct antiinflammatory action through the inhibition of COX2 , dexamethasone can act through the potassium channels of type $\mathrm{C}$ nociceptive fibers through the corticosteroid receptors, affecting activity of this fiber. ${ }^{58}$ A meta-analysis of placebo-controlled studies have shown, that dexamethasone can significantly prolong block of the brachial plexus. Dose of 4-10 $\mathrm{mg}$ can prolong action of local anesthetic from $730 \mathrm{~min}$ to $1306 \mathrm{~min}$. Action of moderate-acting local anesthetic was increased by 175 min, motor block duration increased from 664 to $1102 \mathrm{~min}$ with average difference of $438 \mathrm{~min} .{ }^{59}$.

Farington et al. have shown, that the time of motor and sensor block onset in placebo and dexamethasone groups during the brachial plexus block with mepivacaine was similar, but duration of block increased from 228 to $332 \mathrm{~min}$ in dexamethasone group. ${ }^{60}$

In vitro studies and studies on mice have shown an increased risk of peripheral neurotoxicity and increased neurons dying rate. Dexamethasone as an adjuvant was studied in brachial plexus blocks, talocrural and paravertebral blocks, transversus abdominis plane (TAP) block. ${ }^{61}$ Several studies show positive results such as a decrease in pain score, decrease of postoperative opioid use and decrease of nausea and vomiting. ${ }^{15}$

A meta-analysis from 2011, that included 24 randomized controlled trials (RCT) on 2751 patients showed a decrease of postoperative pain after intravenous dexamethasone in dose of $0.1 \mathrm{mg} / \mathrm{kg} .{ }^{62}$ A recent RCT studied systemic dexamethasone use together with paravertebral blocks during breast surgeries. Results were significant, and showed a decrease of postoperative pain up to $12 \mathrm{hrs}$ after the operations in patients who received dexamethasone, when compared to control group. ${ }^{63}$

A decrease in pain severity score was observed after use of dexamethasone as adjuvant to blocks of anterior wall nerves at 2, 6 and 12 hours. ${ }^{63}$

DeeOliveira et al. in their meta-analysis have shown that intravenous administration of dexamethasone in dose of $0.1 \mathrm{mg} / \mathrm{kg}$ was associated with a decrease in pain score and opioid use. ${ }^{62}$

Another meta-analysis, that included 45 studies and 5796 patients, show lesser use of morphine 2-24 hrs after the operation in patients, who received 1.25 $20 \mathrm{mg}$ dexamethasone. ${ }^{64}$

But randomized clinical study, where $8 \mathrm{mg}$ dexamethasone was used during 52 deliveries through cesarean section did not report a reduction of opioid use 24 hrs after the operation. ${ }^{66}$

It is interesting, that perineural administration decreases frequency of postoperative nausea and vomiting. Recent meta-analysis of 9 RCT's with 575 patients, where dexamethasone was used as an adjuvant for TAP block, a decrease of postoperative nausea and vomiting was observed. ${ }^{66}$

Potential adverse effects of corticosteroids include immunity depression, delayed wound healing and hyperglycemia. However, two big meta-analyses did not find differences in the rate of wound infection and time of healing in study groups compared to control group. ${ }^{62,64}$ Data about hyperglycemia after dexamethasone use as an adjuvant is controversial with some studies indicating increased risk, while others show absence of any difference between the study groups. ${ }^{63,64}$ Tien et al. compared dexamethasone use in diabetic and non-diabetic patients. There was no significant change in glucose levels between 2 study groups. ${ }^{67}$

\subsection{Calcium channel blockers}

Verapamil is used as an adjuvant to local anesthetics during peripheral nerve blocks. It exerts its effect by decreasing the membrane permeability to calcium ions. Verapamil was studied as an adjuvant to bupivacaine in brachial plexus blocks and showed significant positive effect on the block duration. ${ }^{40}$

\subsection{Sodium bicarbonate}

It is an additional substance that can make the time of regional onset faster and increase the depth of block for different local anesthetics. Bicarbonate added to local anesthetics in order to make solution more alkaline, changes dissociation point and increases non-ionized part of the anesthetics, that passes well through the cellular lipid membrane, and makes the block onset faster.

Some anesthetics, such as bupivacaine and ropivacaine precipitate in the alkaline solution, so dose should be lower. Drug permeates lipid membrane faster in non-ionized state and block 
neuron depolarization. But data regarding this theory is controversial. ${ }^{68} \mathrm{pH}$ of local aesthetic solution depends on the method of preparation, so it is impossible to calculate the exact amount of alkaline for the desired result. ${ }^{69}$

Presence of adrenaline in the solution can alter action of sodium bicarbonate causing a decrease of the time of the onset, but also decreases the duration of anesthesia according to Sinnott et al. ${ }^{69,70}$

\subsection{Neostigmine}

Neostigmine potentiates analgesic effect of local anesthetics by increasing acetylcholine levels in the nervous ends. Acetylcholine is a primary mediator in the spinal cord that participates in spinal analgesia. Neostigmine suppress afferent pain impulses to the posterior horns of the spinal cord through muscarinic M1 and M2 receptors. It is also considered that it potentiates anesthesia through increased excretion of nitrogen oxide in the spinal cord..$^{71}$

One of the studies have shown, that combination of $1,2.5$ or $5 \mathrm{mg}$ of neostigmine and morphine led to the prolongation of anesthesia to 8 hours, that demonstrates potentiation of morphine analgesic effect, without any increase in adverse events rate. ${ }^{72}$

Neostigmine as an adjuvant to intravenous analgesia for surgeries on upper limbs decreased time to block onset and prolonged time to first postoperative intake of analgesics. ${ }^{73}$ Postoperative bradycardia was more prominent after the administration of neostigmine. Neostigmine is less effective adjuvant when compared to dexamethasone and midazolam in brachial plexus blocks. ${ }^{74} \mathrm{~A}$ high amount of dosedependent complications such as nausea and vomiting is observed during neostigmine administration. ${ }^{75}$

Spinal neostigmine cause analgesia on animals and humans at a >100 mg doses, but related nausea and vomiting limited its use. ${ }^{76,77}$ Neurotoxicity of neostigmine has also been shown in its perineural use. $^{78}$

There is a big variety of adjuvants nowadays. They represent different classes of drugs, and so act through the different receptors and at different levels of pain conduction, so they have different set of properties, including adverse events. The number of of studies regarding the adjuvant use in regional anesthesia techniques is limited, and the number varies for different adjuvants.
We tried to accumulate available data about different adjuvants according to their main properties described in the publications. Their use can be accompanied by some risk for healthcare professionals and patients. Some adjuvants have specific effects that make them different from all others. For example, main effect of sodium bicarbonate is to facilitate block onset. Physiological basis of this is well known, but preparation of working (alkaline) solution is problematic. This is particularly relevant for bupivacaine and ropivacaine, and usually anesthesiologists want to improve their action.

Alpha-2-adrenoceptor agonists significantly improve block duration, but do not affect the time of onset. Adrenaline have a clear markers of intravascular injection and can prolong action of short- and moderate-acting local anesthetics, but does not prolong action of long-acting anesthetics (the data regarding long-acting anesthetics is controversial). Adrenaline can also prevent toxic action of local anesthetics.

Most of the opioids have some benefits regarding their analgesic effect, when compared systemic and perineural administration. Buprenorphine can be an exclusion with its additional effect on sodium channels. Intrathecal use of opioids is well known, but tramadol is recommended only for epidural infusion.

Regional methods of analgesia are becoming a crucial part of anesthesiologists' practice and the knowledge about adjuvants is developing along with it, so there are more and more studies devoted to it.

\section{Conclusion}

This is a developing area of modern pain management and has more questions than answers. There is a huge need of new high quality studies, including randomized-controlled studies, in this field for available adjuvants, where precise and unified methods should be used for the assessment of different effects of each particular adjuvant on different block features. Also, precise documentation of adverse effects or systemic effects is required for each adjuvant. Combination of adjuvants is not positive at all times. 
Table 1: Summary table of adjuvant to local anesthetics (data in the table is based on the data from the references)

\begin{tabular}{|c|c|c|c|c|c|c|c|c|}
\hline $\begin{array}{l}\text { Effects } \\
\text { Adjuvant }\end{array}$ & $\begin{array}{l}\text { Neuraxial } \\
\text { blocks }\end{array}$ & Perineural & $\begin{array}{l}\text { Facilitates } \\
\text { block } \\
\text { onset }\end{array}$ & $\begin{array}{l}\text { Prolongs } \\
\text { block }\end{array}$ & $\begin{array}{l}\text { Increase } \\
\text { block } \\
\text { strength }\end{array}$ & $\begin{array}{c}\text { Marker of } \\
\text { I/V } \\
\text { injection }\end{array}$ & Adverse events & Source \\
\hline Adrenaline & + & + & - & + & +++ & +++ & $\begin{array}{l}\text { Hypertension, tachycardia, } \\
\text { arrhythmia }\end{array}$ & $20,23,24,25,18,19,22,80$ \\
\hline Dexamethasone & $?$ & + & - & ++ & + & - & $\begin{array}{l}\text { Immunity suppression, increase } \\
\text { risk of infections, wound healing } \\
\text { problems, hyperglycemia }\end{array}$ & $\begin{array}{c}14,15,60,61,62,63,64 \\
65,66,67,80\end{array}$ \\
\hline Ketamine & + & - & - & - & - & - & $\begin{array}{l}\text { Hallucinations, memory defects, } \\
\text { nausea, vomiting, sleepiness }\end{array}$ & $20,40,43,44,45$ \\
\hline Morphine & + & - & - & - & - & - & $?$ & $34,35,36$ \\
\hline Buprenorphine & + & + & & + & + & - & $?$ & $\begin{array}{c}26,27,28,29,30,31,32,33 \\
81,85,83,84,85\end{array}$ \\
\hline Fentanyl & + & - & - & - & - & - & $?$ & 37 \\
\hline Tramadol & + & - & - & - & - & - & $?$ & $40,37,38,39,40,41,42$ \\
\hline Magnesium & + & + & - & + & + & - & Not observed & $17,46,47,48,49$ \\
\hline Dexmedetomidine & + & + & - & +++ & & $+1-$ & Hypotonia, bradycardia & $10,11,12,13,14,15,16,17,86$ \\
\hline $\begin{array}{l}\text { Sodium } \\
\text { bicarbonate }\end{array}$ & - & + & +++ & - & - & - & $?$ & $11,12,16,17$ \\
\hline Neostigmine & + & & + & + & - & - & Nausea, vomiting, bradycardia & \\
\hline Midazolam & - & + & + & + & + & - & Potential neurotoxicity & $50,51,52,53,54$ \\
\hline Verapamil & $?$ & + & $?$ & + & - & - & $?$ & $?$ \\
\hline
\end{tabular}




\section{Conflict of interest}

None declared by the authors

\section{Authors" contribution}

DD: Concept, study work, manuscript editing NO, DK, LE: Study work, manuscript writing

ZO: Manuscript editing

\section{References}

1. Dmytriiev D. Assessment and treatment of postoperative pain in children. Anaesthesia, Pain \& Intensive Care. 2019 Jan 18:392-400. [PubMed] [http://www.apicareonline.com/index.php/APIC/articl e/view/63]

2. Dmytriiev D, Dmytriiev K, Stoliarchuk O, Semenenko A. Multiple organ dysfunction syndrome: what do we know about pain management? A narrative review. Anaesthesia, Pain \& Intensive Care. 2019 Jul 3;23(1). [Free full text]

3. Eisenach JC, De Kock M, Klimscha W. a2-Adrenergic Agonists for Regional AnesthesiaA Clinical Review of Clonidine (1984-1995). Anesthesiology: The Journal of the American Society of Anesthesiologists. 1996 Sep 1;85(3):655-74. [PubMed] DOI: $\underline{10.1097 / 00000542-199609000-00026}$

4. Nguyen V, Tiemann D, Park E, Salehi A. Alpha-2 agonists. Anesthesiology clinics. 2017 Jun 1;35(2):233-45

[PubMed]

DOI: 10.1016/.anclin.2017.01.009

5. Pöpping DM, Elia N, Marret E, Wenk M, Tramèr MR, Warner DS, Warner MA. Clonidine as an adjuvant to local anesthetics for peripheral nerve and plexus blocks: a meta-analysis of randomized trials. The Journal of the American Society of Anesthesiologists. 2009 Aug 1;111(2):406-15. [PubMed] DOI: 10.1097/ALN.0b013e3181aae897

6. McCartney CJ, Duggan E, Apatu E. Should we add clonidine to local anesthetic for peripheral nerve blockade? A qualitative systematic review of the literature. Regional Anesthesia \& Pain Medicine. 2007 Jul 1;32(4):330-8. [PubMed] DOI: 10.1016/i.rapm.2007.02.010

7. YaDeau JT, LaSala VR, Paroli L, Kahn RL, JulesElysée KM, Levine DS, Wukovits BL, Lipnitsky JY. Clonidine and analgesic duration after popliteal fossa nerve blockade: randomized, double-blind, placebocontrolled study. Anesthesia \& Analgesia. 2008 Jun 1;106(6):1916-20. DOI: $10.1213 / a n e .0 b 013 e 318172 \mathrm{fe} 44$

[PubMed]

8. Fournier $R$, Faust $A$, Chassot $O$, Gamulin $Z$. Perineural clonidine does not prolong levobupivacaine $0.5 \%$ after sciatic nerve block using the Labat approach in foot and ankle surgery. Regional Anesthesia \& Pain Medicine. 2012 Sep;37(5):521-4. DOI: $10.1097 / A A P .0 b 013 e 3182606168$

9. Kanazi GE, Aouad MT, Jabbour-Khoury SI, Al Jazzar MD,Alameddine MM, Al-Yaman R, et al. Effect of low- dose dexmedetomidine or clonidine on the characteristics of bupivacaine spinal block. Acta Anaesthesiol Scand 2006;50:222-7. [PubMed] DOI: 10.1111/j.1399-6576.2006.00919.x

10. Abdallah FW, Brull R. Facilitatory effects of perineural dexmedetomidine on neuraxial and peripheral nerve block: a systematic review and meta-analysis. British journal of anaesthesia. 2013 Jun 1;110(6):915-25. [PubMed] DOI: 10.1093/bja/aet066

11. El-Boghdadly K, Brull R, Sehmbi H, Abdallah FW. Perineural Dexmedetomidine Is More Effective Than Clonidine When Added to Local Anesthetic for Supraclavicular Brachial Plexus Block. Anesthesia \& Analgesia [Internet]. Ovid Technologies (Wolters Kluwer Health); 2017 Jun;124(6):2008-20. [PubMed] DOI: $10.1213 /$ ANE.0000000000002014

12. Andersen $\mathrm{JH}$, Jaeger $P$, Grevstad $U$, Estrup $S$, Geisler A, Vilhelmsen F, Dahl JB, Laier GH, Ilfeld BM, Mathiesen 0 . Systemic dexmedetomidine is not as efficient as perineural dexmedetomidine in prolonging an ulnar nerve block. Reg Anesth Pain Med. 2019 Mar 1;44(3):333-40. [PubMed] DOI: 10.1136/rapm-2018-100089

13. Kamibayashi T, Maze M. Clinical uses of alpha2 adrenergic agonists. Anesthesiology 2000:93:1345e9. [PubMed] [http://www.asaabstracts.com/strands/asaabstracts/ abstract.htm?year=2002\&index=15\&absnum=706]

14. Zhang $X, B$ ai $X$. New therapeutic uses for an alpha2 adrenergic receptor agonist-dexmedetomidine in pain management. Neuroscience Letters. 2014 Feb 21:561:7-21. DOI: 10.1016/..neulet.2013.12.039

[PubMed]

15. Koyyalamudi V, Sen S, Patil S, Creel JB, Cornett EM, Fox CJ, Kaye AD. Adjuvant agents in regional anesthesia in the ambulatory setting. Current pain and headache reports. 2017 Jan 1;21(1):6. [PubMed] DOI: 10.1007/s11916-017-0604-1

16. Lirk $P$, Brummett $C M$. Regional anaesthesia, diabetic neuropathy, and dexmedetomidine: a neurotoxic combination?. British Journal of Anaesthesia. 2019 Jan 1;122(1):16-8. [PubMed] DOI: $10.1016 /$ j.bja.2018.09.017

17. Prabhakar A, Lambert T, Kaye RJ, Gaignard SM, Ragusa J, Wheat S, Moll V, Cornett EM, Urman RD, Kaye AD. Adjuvants in clinical regional anesthesia practice: A comprehensive review. Best Practice \& Research Clinical Anaesthesiology. 2019 Dec 1;33(4):415-23. DOI: $10.1016 / j . b p a .2019 .06 .001$

[PubMed]

18. Albert J, Löfström B. Bilateral ulnar nerve blocks for the evaluation of local anaesthetic agents: III. Tests with a New Agent, Prilocaine, and with Lidocaine in Solutions with and without Epinephrine. Acta Anaesthesiologica Scandinavica. 1965 Dec;9(4):203-11. [PubMed]_DOI: 10.1111/j.13996576.1965.tb00507.x

19. Dogru K, Duygulu F, Yildiz K, Kotanoglu MS, Madenoglu H, Boyaci A. Hemodynamic and blockade effects of high/low epinephrine doses during axillary brachial plexus blockade with lidocaine 1.5\%: A randomized, double-blinded study. Regional 
Anesthesia \& Pain Medicine. 2003 Sep 1;28(5):4015. [PubMed] DOI: 10.1016/s1098-7339(03)00225-6

20. Bailard NS, Ortiz J, Flores RA. Additives to local anesthetics for peripheral nerve blocks: Evidence, limitations, and recommendations. American Journal of Health-System Pharmacy. 2014 Mar 1;71(5):37385. [PubMed] DOI: 10.2146/ajhp130336

21. Dogru K, Duygulu F, Yildiz K, Kotanoglu MS, Madenoglu H, Boyaci A. Hemodynamic and blockade effects of high/low epinephrine doses during axillary brachial plexus blockade with lidocaine 1.5\%: A randomized, double-blinded study. Regional Anesthesia \& Pain Medicine. 2003 Sep 1;28(5):4015. [PubMed] DOI: 10.1016/s1098-7339(03)00225-6

22. Song JH, Shim HY, Lee TJ, Jung JK, Cha YD, Lee DI, Kim GW, Han JU. Comparison of dexmedetomidine and epinephrine as an adjuvant to $1 \%$ mepivacaine in brachial plexus block. Korean journal of anesthesiology. 2014 Apr;66(4):283. [PubMed] DOI: 10.4097/kjae.2014.66.4.283

23. Myers RR, Heckman HM. Effects of Local Anesthesia on Nerve Blood FlowStudies Using Lidocaine With and Without Epinephrine. Anesthesiology: The Journal of the American Society of Anesthesiologists. 1989 Nov 1;71(5):757-62. [PubMed] DOI: $10.1097 / 00000542-198911000-00021$

24. Kroin JS, Buvanendran A, Williams DK, Wagenaar B, Moric M, Tuman KJ, Kerns JM. Local anesthetic sciatic nerve block and nerve fiber damage in diabetic rats. Regional Anesthesia \& Pain Medicine. 2010 Jun 1;35(4):343-50. DOI: 10.1097/aap.0b013e3181e82df0

25. Weber A, Fournier R, Van Gessel E, Riand N, Gamulin Z. Epinephrine does not prolong the analgesia of $20 \mathrm{~mL}$ ropivacaine $0.5 \%$ or $0.2 \%$ in a femoral three-in-one block. Anesthesia \& Analgesia. 2001 Nov 1;93(5):1327-31._[PubMed] DOI: $10.1097 / 00000539-200111000-00060$

26. Leffler A, Frank G, Kistner K, Niedermirtl F, Koppert W, Reeh PW, Nau C. Local anesthetic-like inhibition of voltage-gated $\mathrm{Na}+$ channels by the partial $\mu$-opioid receptor agonist buprenorphine. Anesthesiology: The Journal of the American Society of Anesthesiologists. 2012 Jun 1;116(6):1335-46. [PubMed] DOI: $10.1097 / A L N .0 b 013 e 3182557917$

27. Chern SY, Isserman R, Chen L, Ashburn M, Liu R. Perioperative pain management for patients on chronic buprenorphine: a case report. Journal of anesthesia \& clinical research. 2013 Oct 30;3(250). [PubMed] DOI: 10.4172/2155-6148.1000250

28. Al-Hasani R, Bruchas MR. Molecular mechanisms of opioid receptor-dependent signaling and behavior. Anesthesiology: The Journal of the American Society of Anesthesiologists. 2011 Dec 1;115(6):1363-81. [PubMed] DOI: 10.1097/ALN.0b013e318238bba6

29. Kosel J, Bobik P, Tomczyk M. Buprenorphine-the unique opioid adjuvant in regional anesthesia. Expert Review of Clinical Pharmacology. 2016 Mar 3;9(3):375-83. [PubMed]
30. Koppert W, Ihmsen H, Körber N, Wehrfritz A, Sittl R, Schmelz M, Schüttler J. Different profiles of buprenorphine-induced analgesia and antihyperalgesia in a human pain model. Pain. 2005 Nov 1;118(1-2):15-22. [PubMed] DOI: $10.1016 /$ j.pain.2005.06.030

31. Bazin JE, Massoni C, Bruelle P, Fenies V, Groslier D, Schoeffler $P$. The addition of opioids to local anaesthetics in brachial plexus block: the comparative effects of morphine, buprenorphine and sufentanil. Anaesthesia. 1997 Sep;52(9):858-62. [PubMed] DOI: 10.1111/j.1365-2044.1997.174az0311.x

32. Candido KD, Franco CD, Khan MA, Winnie AP, Raja DS. Buprenorphine added to the local anesthetic for brachial plexus block to provide postoperative analgesia in outpatients. Regional Anesthesia \& Pain Medicine. 2001 Jul 1;26(4):352-6. [PubMed] DOI: $10.1053 / \mathrm{rapm} .2001 .23931$

33. Candido KD, Hennes J, Gonzalez S, Mikat-Stevens M, Pinzur M, Vasic V, Knezevic NN. Buprenorphine enhances and prolongs the postoperative analgesic effect of bupivacaine in patients receiving infragluteal sciatic nerve block. Anesthesiology: The Journal of the American Society of Anesthesiologists. 2010 Dec 1;113(6):1419-26.[PubMed] DOI: 10.1097/ALN.0b013e3181f90ce8

34. Karaman S, Kocabas S, Uyar M, Hayzaran S, Firat V. The effects of sufentanil or morphine added to hyperbaric bupivacaine in spinal anaesthesia for caesarean section. European Journal of Anaesthesiology (EJA). 2006 Apr 1;23(4):285-91. [PubMed] DOI: $10.1017 /$ S0265021505001869

35. Axelsson K, Johanzon E, Essving P, Weckström J, Ekbäck G. Postoperative extradural analgesia with morphine and ropivacaine. A double-blind comparison between placebo and ropivacaine 10 $\mathrm{mg} / \mathrm{h}$ or $16 \mathrm{mg} / \mathrm{h}$. Acta anaesthesiologica scandinavica. 2005 Sep;49(8):1191-9. [PubMed] DOI: $10.1111 / \mathrm{j} .1399-6576.2005 .00715 . \mathrm{x}$

36. Flory N, Van-Gessel E, Donald F, Hoffmeyer $P$, Gamulin Z. Does the addition of morphine to brachial plexus block improve analgesia after shoulder surgery?. British journal of anaesthesia. $1995 \mathrm{Jul}$ 1;75(1):23-6. [PubMed] DOI: 10.1093/bja/75.1.23

37. Sousa AM, Ashmawi HA, Costa LS, Posso ID, Slullitel A. Percutaneous sciatic nerve block with tramadol induces analgesia and motor blockade in two animal pain models. Brazilian Journal of Medical and Biological Research. 2012 Feb;45(2):147-52. [PubMed] 879x2011007500164

DOI: $10.1590 / 50100-$

38. Baraka A, Jabbour S, Ghabash M, Nader A, Khoury G, Sibai A. A comparison of epidural tramadol and epidural morphine for postoperative analgesia. Canadian Journal of Anaesthesia. $1993 \mathrm{Apr}$ 1;40(4):308-13. DOI: $10.1007 / B F 03009627$

39. Alhashemi JA, Kaki AM. Effect of intrathecal tramadol administration on postoperative pain after transurethral resection of prostate. British journal of anaesthesia. 2003 Oct 1;91(4):536-40. [PubMed] DOI: $10.1093 /$ bja/aeg213 
40. Prasad GK, Khanna S, Jaishree SV. Review of adjuvants to local anesthetics in peripheral nerve blocks: Current and future trends. Saudi Journal of Anaesthesia. 2020 Jan;14(1):77. [PubMed] DOI: $10.4103 /$ sja.SJA_423_19

41. Alemanno F, Ghisi D, Fanelli A, Faliva A, Pergolotti B, Bizzarri F, Fanelli G. Tramadol and $0.5 \%$ levobupivacaine for single-shot interscalene block: effects on postoperative analgesia in patients undergoing shoulder arthroplasty. Minerva Anestesiol. 2012 Mar 1;78(3):291-6. [PubMed]

42. Mannion S, O'Callaghan S, Murphy DB, Shorten GD. Tramadol as adjunct to psoas compartment block with levobupivacaine $0.5 \%$ : a randomized doubleblinded study. British journal of anaesthesia. 2005 Mar 1;94(3):352-6. [PubMed] DOI: $10.1093 / \mathrm{bja} / \mathrm{aei} 057$

43. Maher DP, Chen L, Mao J. Intravenous ketamine infusions for neuropathic pain management: a promising therapy in need of optimization. Anesthesia \& Analgesia. 2017 Feb 1;124(2):661-74. [PubMed]

44. Niesters M, Martini C, Dahan A. Ketamine for chronic pain: risks and benefits. British journal of clinical pharmacology. 2014 Feb;77(2):357-67. [PubMed] DOI: $10.1111 / \mathrm{bcp} .12094$

45. Lee IO, Kim WK, Kong MH, Lee MK, Kim NS, Choi YS, Lim SH. No enhancement of sensory and motor blockade by ketamine added to ropivacaine interscalene brachial plexus blockade. Acta anaesthesiologica scandinavica. 2002 Aug;46(7):821-6. [PubMed] DOI: 10.1034/j.1399$6576.2002 .460711 . x$

46. Lee AR, Yi HW, Chung IS, Ko JS, Ahn HJ, Gwak MS, Choi DH, Choi SJ. Magnesium added to bupivacaine prolongs the duration of analgesia after interscalene nerve block. Canadian Journal of Anesthesia/Journal canadien d'anesthésie. 2012 Jan 1;59(1):21-7. [PubMed] DOI: 10.1007/s12630-011-9604-5

47. Shamaa HA, Ibrahim M, Eldesuky HL. Magnesium sulfate in femoral nerve block, does postoperative analgesia differ? A comparative study. Egyptian Journal of Anaesthesia. 2014 Apr 1;30(2):169-73. [PubMed] DOl; doi.org/10.1016/j.egja.2013.10.005

48. Vastani N, Seifert B, Spahn DR, Maurer K. Sensitivities of rat primary sensory afferent nerves to magnesium: implications for differential nerve blocks. European Journal of Anaesthesiology (EJA). 2013 Jan 1;30(1):21-8. [PubMed] DOI: 10.1097/EJA.0b013e32835949ab

49. Alagol A, Calpur OU, Usar PS, Turan N, Pamukcu Z. Intraarticular analgesia after arthroscopic knee surgery: comparison of neostigmine, clonidine, tenoxicam, morphine and bupivacaine. Knee Surgery, Sports Traumatology, Arthroscopy. 2005 Nov $1 ; 13(8): 658-63$ [PubMed] DOI: 10.1007/s00167-004-0612-7

50. Banati RB, Myers R, Kreutzberg GW. PK ('peripheral benzodiazepine')-binding sites in the CNS indicate early and discrete brain lesions: microautoradiographic detection of [3H] PK 11195 binding to activated microglia. Journal of neurocytology. 1997 Feb 1;26(2):77-82. [PubMed] DOI: 10.1023/a:1018567510105

51. Kondo D, Saegusa H, Yabe R, Takasaki I, Kurihara $\mathrm{T}$, Zong S, Tanabe T. Peripheral-type benzodiazepine receptor antagonist is effective in relieving neuropathic pain in mice. Journal of pharmacological sciences. 2009:0904280239.PubMed] DOI: 10.1254/jphs.09028fp

52. Gupta P, Saxena A, Chaudhary L. Effect of pregabalin premedication on the requirement of anesthetic and analgesic drugs in laparoscopic cholecystectomy: randomized comparison of two doses. Anesthesia, essays and researches. 2017 Apr;11(2):330. [PubMed] DOI: 10.4103/0259$\underline{1162.186862}$

53. Ibrahim M, Gomaa E. Efficacy of midazolam addition to local anesthetic in peribulbar block. Der Anaesthesist. 2019 Mar 1;68(3):143-51. [PubMed] DOI: $10.1007 / \mathrm{s} 00101-018-0525-3$

54. Knight JB, Schott NJ, Kentor ML, Williams BA. Neurotoxicity questions regarding common peripheral nerve block adjuvants in combination with local anesthetics. Current opinion in anaesthesiology. $2015 \quad$ Oct;28(5):598. [PubMed] DOI: 10.1097/ACO.0000000000000222

55. Reinhart DJ, Stagg KS, Walker KG, Wang WP, Parker CM, Jackson HH, Walker EB. Postoperative analgesia after peripheral nerve block for podiatric surgery: clinical efficacy and chemical stability of lidocaine alone versus lidocaine plus ketorolac. Regional Anesthesia \& Pain Medicine. 2000 Sep 1;25(5):506-13. DOI: $10.1053 / \mathrm{rapm} .2000 .7624$

[PubMed]

56. Mirkheshti A, Saadatniaki A, Salimi A, Rasi AM, Memary $\mathrm{E}$, Yahyaei $\mathrm{H}$. Effects of dexmedetomidine versus ketorolac as local anesthetic adjuvants on the onset and duration of infraclavicular brachial plexus block. Anesthesiology and Pain Medicine. 2014 Aug;4(3). [PubMed] DOI: 10.5812/aapm.17620

57. Akdogan A, Eroglu A. Comparison of the effect of lidocaine adding dexketoprofen and paracetamol in intravenous regional anesthesia. BioMed research international. 2014 Jan 1;2014. [PubMed] DOI: $\underline{10.1155 / 2014 / 938108}$

58. Attardi B, Takimoto K, Gealy R, Severns C, Levitan ES. Glucocorticoid induced up-regulation of a pituitary $\mathrm{K}+$ channel mRNA in vitro and in vivo. Receptors \& channels. 1993 Jan 1;1(4):287-93. [PubMed]

59. Choi S, Rodseth R, McCartney CJ. Effects of dexamethasone as a local anaesthetic adjuvant for brachial plexus block: a systematic review and metaanalysis of randomized trials. British journal of anaesthesia. 2014 Mar 1;112(3):427-39. [PubMed] DOI: $10.1093 / \mathrm{bja} / \mathrm{aet} 417$

60. Parrington SJ, O'Donnell D, Chan VW, BrownShreves D, Subramanyam R, Qu M, Brull R. Dexamethasone added to mepivacaine prolongs the duration of analgesia after supraclavicular brachial plexus blockade. Regional Anesthesia \& Pain Medicine. 2010 Aug 1;35(5):422-6. [PubMed] DOI: $\underline{10.1097 / A A P .0 b 013 e 3181 \mathrm{e} 85 \mathrm{eb} 9}$ 
61. Emelife PI, Eng MR, Menard BL, Myers AS, Cornett EM, Urman RD, Kaye AD. Adjunct medications for peripheral and neuraxial anesthesia. Best Practice \& Research Clinical Anaesthesiology. 2018 Jun 1;32(2):83-99.

DOI: $10.1016 / j . b p a .2018 .06 .011$

62. De Oliveira GS, Almeida MD, Benzon HT, McCarthy RJ. Perioperative single dose systemic dexamethasone for postoperative PainA metaanalysis of randomized controlled trials. Anesthesiology: The Journal of the American Society of Anesthesiologists. 2011 Sep 1;115(3):575-88. [PubMed] DOI: 10.1097/ALN.0b013e31822a24c2

63. Bakeer AH, Abdallah NM, Kamel MA, Abbas DN, Ragab AS. The impact of intravenous dexamethasone on the efficacy and duration of analgesia of paravertebral block in breast cancer surgery: a randomized controlled trial. Journal of Pain Research. 2019;12:61. [PubMed] DOI: $10.2147 / J P R . S 181788$

64. Waldron NH, Jones CA, Gan TJ, Allen TK, Habib AS. Impact of perioperative dexamethasone on postoperative analgesia and side-effects: systematic review and meta-analysis. British journal of anaesthesia. 2013 Feb 1;110(2):191-200. [PubMed] DOI: 10.1093/bja/aes431

65. Ituk $U$, Thenuwara $K$. The effect of a single intraoperative dose of intravenous dexamethasone 8 $\mathrm{mg}$ on post-cesarean delivery analgesia: a randomized controlled trial. International journal of obstetric anesthesia. 2018 Aug 1;35:57-63. [PubMed] DOI: $10.1016 /$ /.jijoa.2018.03.008

66. Zhang D, Zhou C, Wei D, Ge L, Li Q. Dexamethasone added to local anesthetics in ultrasound-guided transversus abdominis plain (TAP) block for analgesia after abdominal surgery: A systematic review and meta-analysis of randomized controlled trials. PloS one. 2019 Jan 8;14(1):e0209646. [PubMed] DOI: 10.1371/journal.pone.0209646

67. Tien M, Gan TJ, Dhakal I, White WD, Olufolabi AJ, Fink R, Mishriky BM, Lacassie HJ, Habib AS. The effect of anti-emetic doses of dexamethasone on postoperative blood glucose levels in non-diabetic and diabetic patients: a prospective randomized controlled study. Anaesthesia. 2016 Sep;71(9):103743. [PubMed] DOI: 10.1111/anae.13544

68. Bailard NS, Ortiz J, Flores RA. Additives to local anesthetics for peripheral nerve blocks: Evidence, limitations, and recommendations. American Journal of Health-System Pharmacy. 2014 Mar 1;71(5):37385. [PubMed] DOI: 10.2146/ajhp130336

69. Sinnott CJ, Garfield JM, Thalhammer JG, Strichartz GR. Addition of sodium bicarbonate to lidocaine decreases the duration of peripheral nerve block in the rat. Anesthesiology: The Journal of the American Society of Anesthesiologists. 2000 Oct 1;93(4):104552. [PubMed] DOI: $10.1097 / 00000542-200010000-$ $\underline{00028}$

70. Chow MY, Sia AT, Koay CK, Chan YW. Alkalinization of lidocaine does not hasten the onset of axillary brachial plexus block. Anesthesia \& Analgesia. 1998 Mar 1;86(3):566-8. [PubMed] DOI: $\underline{10.1097 / 00000539-199803000-00024}$
71. Li DP, Chen SR, Pan YZ, Levey Al, Pan HL. Role of presynaptic muscarinic and GABAB receptors in spinal glutamate release and cholinergic analgesia in rats. The Journal of physiology. 2002 Sep;543(3):807-18. DOI: $\underline{10.1113 / \text { pphysiol.2002.020644 }}$

72. Almeida RA, Lauretti GR, Mattos AL. Antinociceptive effect of low-dose intrathecal neostigmine combined with intrathecal morphine following gynecologic surgery. Anesthesiology: The Journal of the American Society of Anesthesiologists. $2003 \mathrm{Feb}$ 1;98(2):495-8. [PubMed] DOI: $10.1097 / 00000542-$ 200302000-00031

73. Turan A, Karamanlýoglu B, Memis D, Kaya G, Pamukçu Z. Intravenous regional anesthesia using prilocaine and neostigmine. Anesthesia \& Analgesia. 2002 Nov 1;95(5):1419-22. [PubMed] DOI: $\underline{10.1097 / 00000539-200211000-00058}$

74. Yadav RK, Sah BP, Kumar P, Singh SN. Effectiveness of addition of neostigmine or dexamethasone to local anaesthetic in providing perioperative analgesia for brachial plexus block: a prospective, randomized, double blinded, controlled study. Kathmandu University Medical Journal. 2008:6(3):302-9. DOI: $10.3126 /$ kumj.v6i3.1704

[PubMed]

75. Lauretti GR, Mattos AL, Reis MP, Prado WA. Intrathecal neostigmine for postoperative analgesia after orthopedic surgery. Journal of clinical anesthesia. 1997 Sep 1;9(6):473-7. [PubMed] DOI: $10.1016 / \mathrm{s} 0952-8180(97) 00103-7$

76. Hood DD, Eisenach JC, Tuttle R. Phase I safety assessment of intrathecal neostigmine methylsulfate in humans. Anesthesiology: The Journal of the American Society of Anesthesiologists. $1995 \mathrm{Feb}$ 1;82(2):331-43. [PubMed] DOI: $10.1097 / 00000542-$ 199502000-00003

77. Eisenach JC, Hood DD, Curry R. Phase I human safety assessment of intrathecal neostigmine containing methyl-and propylparabens. Anesthesia \& Analgesia. $\quad 1997$ Oct 1;85(4):842-6. [PubMed] DOI: $10.1097 / 00000539-199710000-$ $\underline{00024}$

78. Demirel E, Ugur HC, Dolgun H, Kahilogullari G, Sargon MF, Egemen N, Kecik Y. The neurotoxic effects of intrathecal midazolam and neostigmine in rabbits. Anaesthesia and intensive care. 2006 Apr;34(2):218-23. DOI: $10.1177 / 0310057 \times 0603400204$

79. Eledjam JJ, Deschodt J, Viel EJ, Lubrano JF, Charavel $P$, d'Athis F, et al. Brachial plexus block with bupivacaine: effects of added alpha-adrenergic agonists: comparison between clonidine and epinephrine. Can J Anaesth. 1991 Oct;38(7):870-5. [PubMed] DOI: $10.1007 /$ BF03036962

80. Moallemy A, Jarineshin $H$, Fekrat $F$, Baghaaei AA, Kamali M, Razavi BM, Shaerzadeh Z. Effect of adding dexamethasone to lidocaine on the quality of intravenous regional anesthesia for upper extremity orthopedic operations: A randomized clinical trial. Electronic physician. 2018 Apr;10(4):6631. [PubMed] DOI: $\underline{10.19082 / 6631}$ 
81. Stern EE. Buprenorphine and the anesthesia considerations: a literature review.Nurse Anesthesia Capstones 2015[PubMed] [https://dune.une.edu/na_capstones/2]

82. Jones HE. Practical considerations for the clinical use of buprenorphine. Science \& Practice Perspectives. 2004 Aug;2(2):4. [PubMed] DOI: 10.1151/spp04224

83. Kress HG. Clinical update on the pharmacology, efficacy and safety of transdermal buprenorphine. European Journal of Pain. 2009 Mar 1;13(3):219-30. [PubMed] DOI: 10.1016/j.ejpain.2008.04.011

84. Pergolizzi J, Aloisi AM, Dahan A, Filitz J, Langford R, Likar R, Mercadante S, Morlion B, Raffa RB, Sabatowski R, Sacerdote P. Current knowledge of buprenorphine and its unique pharmacological profile. Pain Practice. 2010 Sep;10(5):428-50. [PubMed] DOI: 10.1111/j.1533-2500.2010.00378.x

85. Candido KD, Winnie AP, Ghaleb AH, Fattouh MW, Franco $C D$. Buprenorphine added to the local anesthetic for axillary brachial plexus block prolongs postoperative analgesia. Regional Anesthesia \& Pain Medicine. 2002 Mar 1;27(2):162-7._[PubMed] DOI: 10.1053/rapm.2002.30671

86. Kanazi GE, Aouad MT, Jabbour-Khoury SI, Al Jazzar $\mathrm{MD}$, Alameddine MM, Al-Yaman R, Bulbul M, Baraka AS. Effect of low-dose dexmedetomidine or clonidine on the characteristics of bupivacaine spinal block. Acta anaesthesiologica scandinavica. 2006 Feb;50(2):222-7. [PubMed] DOI: 10.1111/j.13996576.2006.00919.x 